\title{
レーザーブレイクダウンによる非接触加振法を用いた膜構造の振動モード実験 Modal Test of Membrane Structures Using Non-Contact Excitation Generated by Laser-Induced Breakdown
}

\author{
$\bigcirc$ 学 新里 淳 (北大) \\ 正 細矢 直基（芝工大）
}

正 梶原 逸朗（北大）

\author{
Jun SHINZATO, Hokkaido University, N13, W8, Kita-ku, Sapporo, Hokkaido, Japan \\ Itsuro KAJIWARA, Hokkaido University \\ Naoki HOSOYA, Shibaura Institute of Technology
}

\begin{abstract}
This paper proposes an innovative vibration testing method for membrane structures based on impulse response excited by laser. Non-contact impulse force can be applied to a structure by using a shock wave generated by laser-induced breakdown in air. A high-power YAG pulse laser is used in the present vibration testing system for generating the laser-induced breakdown in acoustic fields. The laser excitation makes a precise measurement of the frequency response in wide frequency range possible because an ideal impulse force is applied to a point on the structure. Using a laser Doppler vibrometer to detect a response of the structure, both non-contact laser excitation and measurement are achieved in the vibration testing system. Furthermore, vibration mode shapes of the membrane structure can be extracted by conducting a multi-point measurement. The validity of the present vibration testing system is verified by measuring the frequency response data and extracting the mode shapes of a square Kapton membrane structure.
\end{abstract}

Key Words: Laser, Vibration, Laser-Induced Breakdown, Membrane, Non-Contact Excitation, Modal Test

\section{1. 緒言}

膜構造とは，膜材料とその他の部材を組み合わせた構造物 であり，ドームやスタジアムなどの建築構造のほか, パネル ディスプレイに用いられる光学フィルムや, センサ/アクチ ユエータとして用いられる PVDF フィルムなど，幅広い分野 で利用されている，建築構造において，膜構造は透光性に優 れるという性質を持つため, 日中の照明コストを抑えること ができ，また軽量で伸縮性をもつため地震による影響を受け にくいという特徴を持つ.さらにその軽さと柔軟性により， 膜構造は小さく折りたたむことが可能で，輸送効率の向上お よび輸送コストの低減を実現できる．このため近年では宇宙 環境における膜構造の利用も進んできており，2010年 5 月に JAXA によって打ち上げられた小型ソーラーセイル電力実証 機 IKAROS も膜構造の一種である. 本研究では,このような 膜構造物に対する新しい振動試験システムの構築を目指す。

膜構造の振動実験を行う際, 従来のように振動の入力源と して加振器やアクチュエータなどを用いると, 軽量かつ柔軟 な膜構造の動特性はこれらの取り付けデバイスの影響を大き く受けてしまう。そこで本研究では, 高出力パルスレーザー を用い, レーザーブレイクダウン（Laser-Induced Breakdown : LIB） (1)により発生する理想的な点音源を利用して, 膜構造の
加振を行う. レーザー加振法の利点は, 加振器やアクチュエ ータのような加振デバイスを対象物に取り付けることなく, 測定対象物に非接触で加振力を作用させられることである. この加振力が理想的なインパルス入力となるため, 測定対象 物を高次のモードまで励起させることができる. また, 出力 計測もレーザードップラー振動計（LDV）を用いて行うこと により, 完全非接触で振動試験を行うことができ, 適用範囲 の拡大とともに計測の信頼性を高めることができる.さらに， レーザー加振法のもう一つの利点として, 高い再現性が挙げ られる.インパルスハンマによる加振方法では，作用させる 加振力の正確さや再現性は技術者のスキルに依存し, 対象構 造物によっては信頼性の高い計測を行うことが困難であるが， レーザー加振法ではレーザーエネルギーで規定された加振力 が作用するため，高度な再現性を保証することができる。

LIB により生成される音響加振力を膜構造に作用させ，計 測される膜構造の振動特性を評価する. 本振動試験において, レーザー出力および LIB の生じる点と対象物との距離が計測 結果に与える影響について調べる．また，先行研究において 開発した，レーザー光を直接対象物に照射したときに生じる レーザーアブレーション（Laser Ablation：LA）を利用した加 振方法 ${ }^{(2)(3)}$ と, LIB による加振方法での膜構造の振動応答の違 
いを検証する，さらに, レーザー加振時において LDVによる 多点計測を実施し, 各計測点の周波数スペクトルから膜構造 のモード形を抽出できることを示す．これらの試験および評 価を通じ, LIB 加振法および本振動試験システムの有効性を 検証する.

\section{2. 非接触レーザー加振法}

LA とは，高エネルギーのレーザーを物体に照射した際に， 物体の表面から原子や分子, イオンなどが爆発的に放出され る現象である. 本手法では, 高出力のパルスレーザーを凸レ ンズで集光させることにより, 膜構造の表面に取り付けたア ルミプレート上の 1 点で LA を発生させ, 対象物を振動させ ている. 図 1 に LA 発生の原理を示す.レーザーが照射され た際に，アルミニウムプレートから放出される原子，分子， イオンの質量を $\Delta \mathrm{m}$, 放出速度をvとすると, その運動量は $\Delta \mathrm{mv}$ となる.この運動量の変化はすなわち力積であり,この力積 が理想的なインパルスカとして物体表面の法線方向に作用す る. LAによる入力の時刻歴応答とパワースペクトルの関係は,

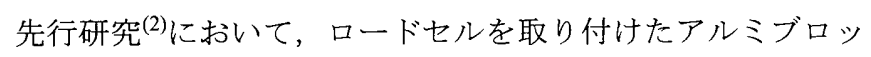
クを用いて, LAによる入力の応答と周波数スペクトルを評価 した. その結果, 理想的なインパルス入力と $40 \mathrm{kHz}$ 帯域まで フラットな周波数スペクトルが実現され, 供試体の入出力を ロードセルと加速度計で計測することにより，40kHz 帯域ま で正確な周波数応答が得られることを FEM による解析結果 との比較から確認した. LAによる加振法の適用範囲は広いが, レーザーを対象物に照射した際に, 被照射面に極微小の損傷 が生じてしまう。そのため, 本加振法による実験では, 膜構 造が損傷しないよう膜上のレーザー照射点に小さいアルミプ レートを取り付ける.

LIB は，レーザービームを気体中に集光すると多光子過程 により原子・分子が複数の光子を吸収して電子を放出し，力 スケード過程によりプラズマを形成させることをいう。この プラズマエネルギーの一部が消費されることで形成された衝
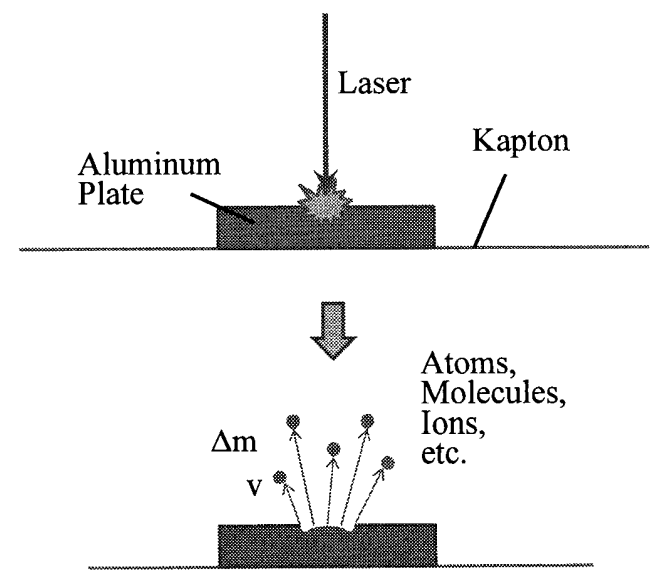

Fig.1 Excitation force generated by LA
撃波が，LIB による音源となる．LIB を利用した音響加振技 術に関する先行研究(1)において, LIB を発生させたときの音圧 をマイクロフォンによって計測した結果, LIB により生成さ れた点音源は, 無指向性かつパルス幅 $20 \mu \mathrm{s}$ のほぼ理想的なイ ンパルスカであり, 音響加振源としては数百 $\mathrm{kHz}$ 程度の高周 波数帯域までの成分を含むことが確認できている. LIB 加振 法の利点は, LA 加振と異なり, 計測対象にレーザーを直接照 射しないため, 完全非接触の加振が実現され, 対象構造物に 何ら損傷を与えないことである.

理想的なインパルス入力に対し, 出力のフーリエ変換は系 の伝達関数を表す. いま, 入力の時刻歴応答を $f(t)$, 出力の 時刻歴忘答を $x(t)$ とすると, それぞれのフーリエ変換 $F(\omega)$ お よびX $(\omega)$ は以下のように記述される.

$$
\begin{aligned}
& F(\omega)=\int_{-\infty}^{\infty} f(t) e^{-i \omega t} d t \\
& X(\omega)=\int_{-\infty}^{\infty} x(t) e^{-i \omega t} d t
\end{aligned}
$$

一方, 出力 $x(t)$ はインパルス応答関数 $h(t)$ と入力 $f(t)$ の畳み込 み積分で表現することができる.

$$
x(t)=\int_{-\infty}^{\infty} h(t-\tau) f(\tau) d \tau
$$

式(3)のフーリエ変換は畳み込み積分の性質より以下のよう になる.

$$
X(\omega)=H(\omega) F(\omega)
$$

ここで, $H(\omega)$ はシステムの周波数応答関数である. また, $f(t)$ がインパルスカであるとみなせ, 理想的にはディラックのデ ルタ関数であるとき, $f(t)$ のフーリエ変換は $F(\omega)=1$ となる. ゆえに，式(4)は以下のようになる.

$$
X(\omega)=H(\omega)
$$

式(5)より, 出力の時刻歴応答 $x(t)$ のフーリエ変換は周波数応 答関数となることがわかる.

LA および LIB による入力は, 先行研究によりほぼ理想的 なインパルス入力であると確認されているため，これらのレ 一ザー加振により得られる周波数スペクトルは, 力の大きさ

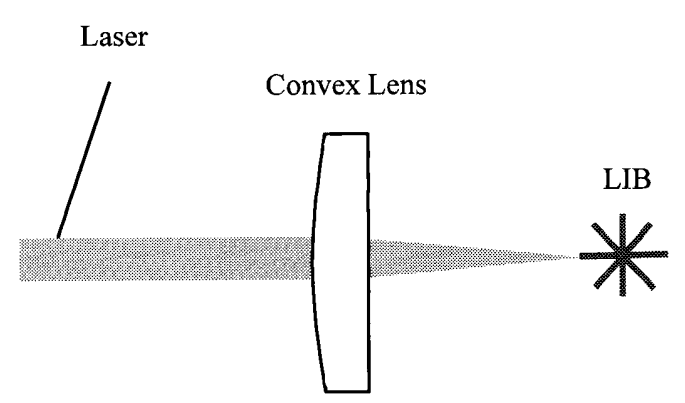

Fig.2 Acoustic excitation system by LIB 
に関し非正規化の周波数応答関数とみなすことができる．ま た, レーザー加振法では, 加振力特性の再現性が極めて高い ことから, 出力の周波数スペクトルにより, 系の周波数特性 を評価することができる。

\section{3. 実験装置}

\section{$3 \cdot 1$ 膜鹤造}

対象とする膜構造の写真を図 3 に示す. 本研究において使 用する膜構造の材料は, 東レ・デュポン社のカプトンと呼ば れるポリイミドフィルム膜で， $-269^{\circ} \mathrm{C}$ の超低温領域から約 $400^{\circ} \mathrm{C}$ 高温領域まで耐えうる性質を持つ. そのため, 宇宙空 間などの極限環境においても利用されている. 膜の四隅には， おもりの重力を利用した $6.9 \mathrm{~N}$ の張力がワイヤでかけられて おり，張られた状態が保たれている.

膜の寸法は, $200 \mathrm{~mm} \times 200 \mathrm{~mm}$ であり, 厚さは $50 \mu \mathrm{m}$ である. 振動の計測には LDV を用いるため, 膜構造上の計測点にシー ト状のリフレクターを貼り付ける. 本研究では, 膜構造の振 動モード形抽出を一つの目的としているため, 多点での計測 を行う．そこで，図 3 に示すように，リフレクターを貼りつ ける計測点の閒隔を $30 \mathrm{~mm}$ とし， $7 \times 7$ の 49 点の計測点を膜 構造上に設けた。 また, 別途, 膜構造の中央から $50 \mathrm{~mm}$ の位 置に計測点 $\mathrm{A}$ を設け，さまざまな試験条件における周波数特 性を評価するための測定点とする. なお，LAによる振動試験 おいては，膜の損傷を防ぐため，膜の中央（加振点）に $13.8 \mathrm{~mm} \times 13.8 \mathrm{~mm} \times 1.5 \mathrm{~mm}$ のアルミニウムプレートを貼り 付ける.

\section{$3 \cdot 2$ 振動試験システム}

LIB による振動計測システムの構成の概略図を図 4 に示す. 実験装置は, YAG レーザー (Continuum Surelite III), 凸レンズ(焦 点距離 ; 200mm), 膜構造, LDV (ONOSOKKI LV-1720), お よび振動解析システム（A/D; NI PXI-1042Q, PXI-4472B,

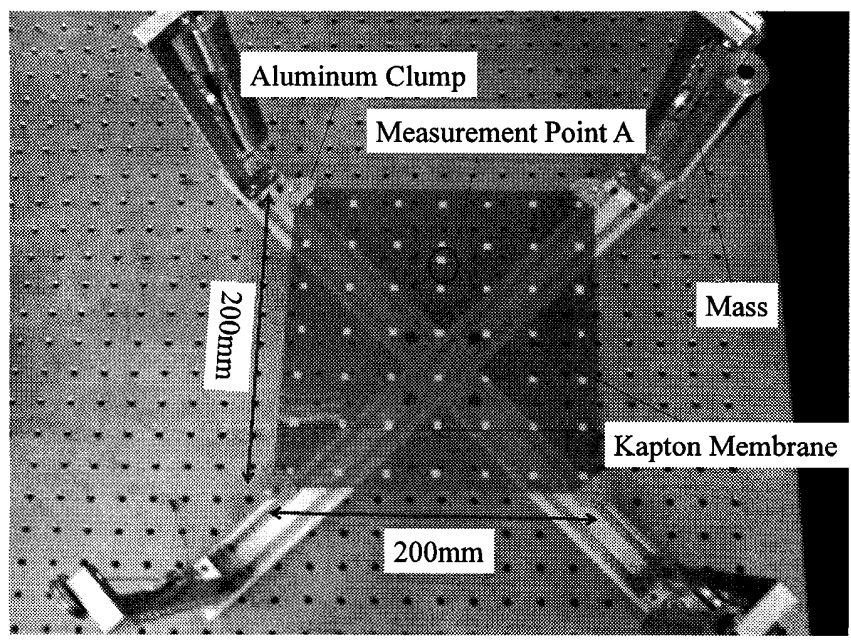

Fig.3 Overall view of membrane structure
Software; キャテック CAT-System）から成る. YAG レーザ 一から発せられたレーザー光は凸レンズで集光され，レーザ ーブレイクダウンが発生する.これにより音響加振力が膜構 造に作用し，膜が振動する．そして，膜構造上部に設置した LDVにより，計測点における膜面法線方向の振動速度を計測 する. 計測される出力信号から，振動解析システムで出力応 答の周波数スペクトルを解析し，振動特性を評価する．本実 験において，加振点は膜構造の中央とする．また，LIB の際 に発生するプラズマ光が LDVによる振動計測に影響しない よう，膜構造の下側で LIB を発生させる.

一方，LAによる振動試験では，YAG レーザーから発せら れたレーザー光を誘多膜ミラーによって膜面方向一反射させ た後, 凸レンズを経て膜中央に張り付けたアルミプレート上 に集光され，レーザーアブレーションが発生する. そして， アルミプレート上に加振力が作用し，膜構造が振動する．振 動計測に関しては，LIBによる振動試験と同様である。

\section{4. 实験結果}

\section{4 －1 LA 加振および LIB 加振の振動応答比較}

LA 加振および LIB 加振による膜構造の振動応答を比較す る. LA を用いて膜構造の加振を行う際には, 膜の損傷を避け るため，加振点すなわち膜構造の中央にアルミプレートを貼 り付ける. LIB 加振では, このアルミプレートは必要ないが, LA 加振による振動特性と比較するため, アルミプレートが有 無の両ケースについて LIBによる加振実験を行う.

アルミプレートを中央に貼り付けた膜構造をLAおよび LIB により加振したときの周波数スペクトル，およびアルミ プレートを貼っていない膜構造を LIB によって加振したとき の周波数スペクトルを図 5 に示す. 計測点は図 3 における点 A である.ここで，レーザ一出力は $600 \mathrm{~mJ}$ ，LIB 加振におけ る点音源と膜との距離は $10 \mathrm{~mm}$ である.

LA 加振および LIB 加振ともに十分明膫に共振ピークが現

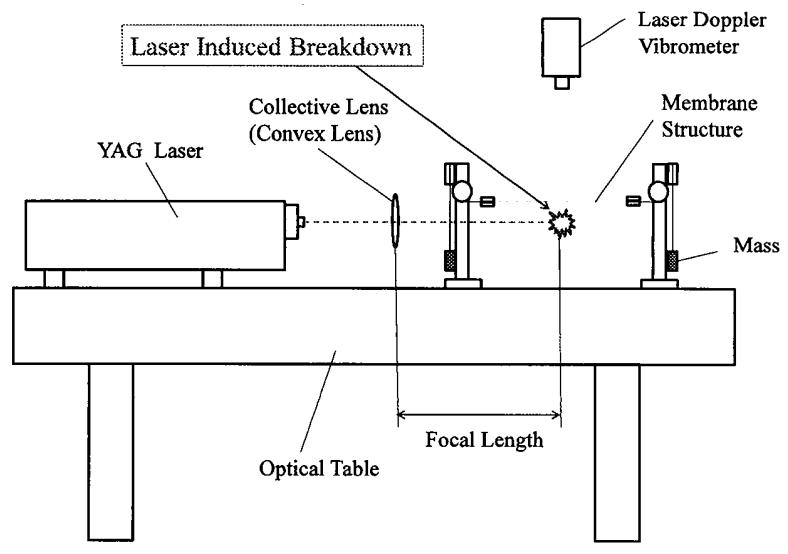

Fig.4 Schema of experimental system for LIB 
れており，両者とも膜構造の加振方法として適していること がわかる，また，アルミプレートを貼り付けた膜では，プレ 一トの質量効果により，それがない場合に対して共振周波数 が低下する傾向が見てとれ，LA 加振および LIB 加振による

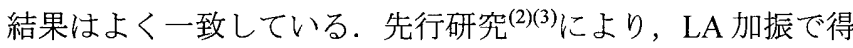
られる周波数応答の信頼性は検証されているので，この結果 は，LIB 加振においても信頼性の高い点加振および振動計測 が実現できていることを意味する．同時に，アルミプレート を貼り付けていない膜構造の LIB 加振実験結果も高い信頼性 を有していると判断できる.

以上の結果から，完全非接触かつ非破壊で加振力を作用さ せることができる LIB 加振法の有効性が明らかになった，以 降では，膜面上にアルミプレートを貼り付けず, LIB 加振法 を用いて振動実験を行う。

\section{$4 \cdot 2$ 膜構造の振動モード形状の抽出}

多点計測で得られた周波数スペクトルから，各計測点のゲ インおよび位相情報を用いて, 膜構造のモード形を抽出する. レーザー出力は $600 \mathrm{~mJ}$, LIB による点音源と膜との距離は $10 \mathrm{~mm}$ である。 まず，全計測点 49 点のパワースペクトルをす べて足し合わせ，モード抽出の対象とする共振ピークを顕在 化させる. 次に，対象とする共振ピーク（固有振動数）を選 択し，それに対応する振動モード形を抽出する．全計測点の パワースペクトルを合計したデータから，抽出するモードの 周波数を選択することにより，特定の計測点が節になるモ一 ドの見落としを防ぐことができる．

全計測点のパワースペクトルをすべて足し合わせた特性を 図 6 に示す。そして，120Hz 以下の周波数帯域において，図 6 中の○で示した 10 個の共振ピークに関する振動モード形状 を抽出する。それぞれの振動モード形を，図 6 の○印左から $\mathrm{M} 1, \mathrm{M} 2, \cdots \cdot ・, \mathrm{M} 10$ とする. M1 以下の低周波数帯域にお ける共振ピークは膜構造自体の変形ではない剛体モードであ ることを実験により確認している．各計測点の周波数スペク トルから抽出した振動モード形の結果を図 7 に示す。この結 果から，対象とする全ピークについて，明瞭な振動モード形

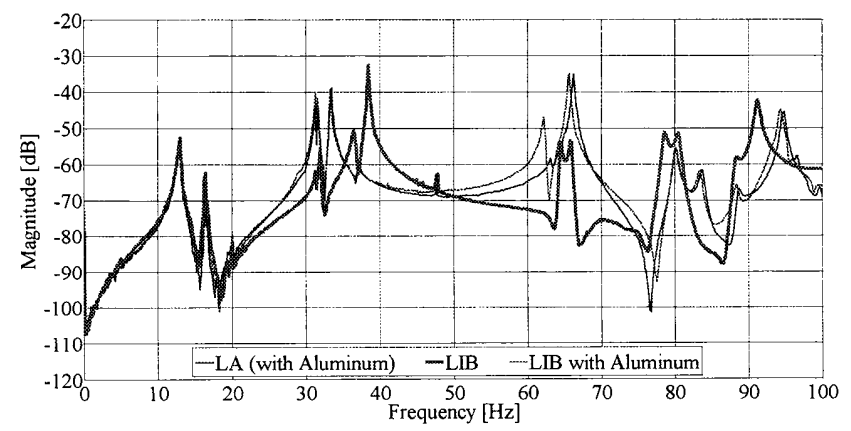

Fig.5 Frequency spectra at A with LA and LIB excitation
が抽出できていることがわかる. 図 7(a)は, 膜構造の 1 次の 基本弾性モードであり，膜面の中央が腹になるモード形であ る。また，図 7(b)と(c)および(f)と(g)など，対称モードとなる ペアもいくつか見てとれる，膜構造が完全な対象構造であれ ば，これらペアの固有振動数は重根として現れるはずだが，

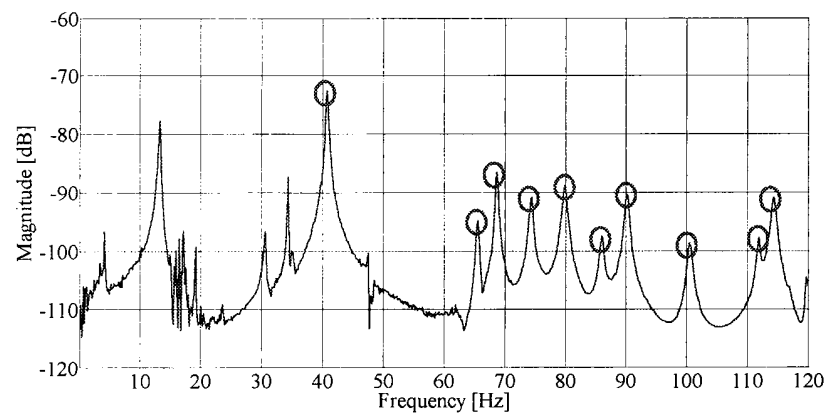

Fig.6 Sum of frequency spectra with LIB excitation
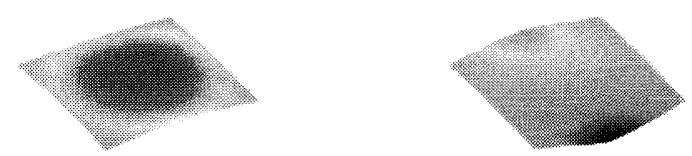

(a) $\mathrm{M} 1: 40.8 \mathrm{~Hz}$

(b) $\mathrm{M} 2: 65.5 \mathrm{~Hz}$
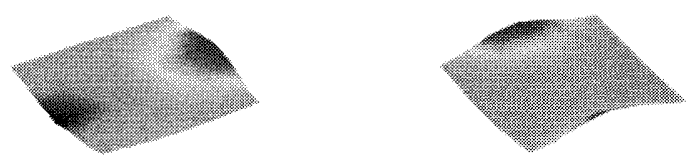

(c) $\mathrm{M} 3: 68.6 \mathrm{~Hz}$

(d) $\mathrm{M} 4: 74.4 \mathrm{~Hz}$
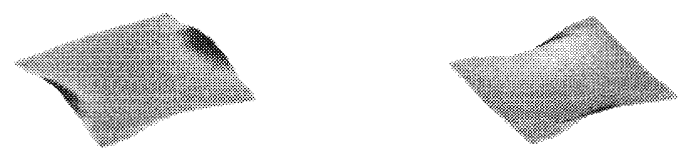

(e) $\mathrm{M} 5: 79.8 \mathrm{~Hz}$

(f) $\mathrm{M} 6: 85.9 \mathrm{~Hz}$
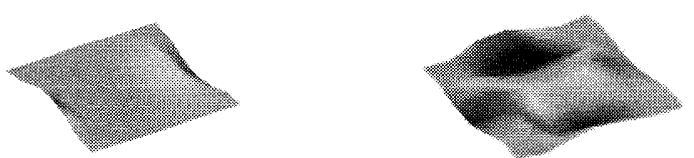

(g) $\mathrm{M} 7: 90.1 \mathrm{~Hz}$

(h) M8: $100.5 \mathrm{~Hz}$
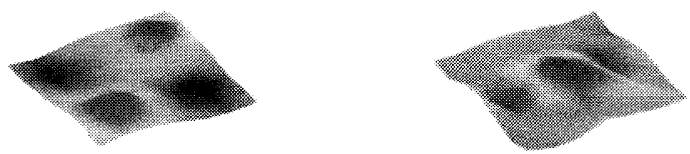

(i) $\mathrm{M} 9: 111.9 \mathrm{~Hz}$

(j) $\mathrm{M} 10: 114.4 \mathrm{~Hz}$

Fig. 7 Mode shapes extracted with frequency spectra 
構造の非対称性から本実験結果ではわずかなずれを生じてい る.

以上の結果から, LIB 加振により, 膜構造の振動特性が高 精度に計測され，これにより高い効率および信頼性の下で振 動モード形を抽出できることが明らかになった.

\section{5. 結言}

本研究では, YAG パルスレーザーで形成される LIB を点音 源とした音響加振法により，膜構造の振動特性を計測・評価 する振動試験システムを構築した。そして，LDVを用いた多 点計測結果から, 振動モード形の抽出を行い, 以下の結論を 得た.

1. YAG パルスレーザーにより LIB を発生させ, 生成され る点音源を利用した音響加振法を用い, 振動計測法とし て LDVによる非接触レーザー計測方式を採用すること で，軽くて柔軟な膜構造に対し，計測精度および信頼性 の高い完全非接触かつ非破壊の振動試験システムを実 現した.

2. LIB 加振と LA 加振の結果を比較し, 両者がよい一致を 示すことから, LIB 加振による振動計測法の高い信頼性 を明らかにすると同時に, 完全非接触および非破壊とい う観点から, LIB 加振の優位性を検証した。

3. LIB 加振時に LDV で多点計測を行うことにより，高い 効率および信頼性の下で振動モード形の抽出が可能に なることを明らかにした。

\section{触辞}

本研究は, 日本学術振興会 - 科学研究費補助金（基盤研究 (A) (22246027)，若手研究（A）（22686025）および挑戦 的萌芽研究 (24656158)) の援助を受けて遂行した.

ここに，深く感謝の意を表する。

\section{参考文献}

（1）細矢直基, 永田将希, 梶原逸朗, レーザーブレイクダウ ンによる点音源を用いた微小空間の音響加振法, 日本機 械学会論文集 C 編, Vol.78, No.787 (2012), pp.770-782

(2) 細矢直基, 梶原逸朗, 反町仁, レーザーアブレーション を用いたインパルス加振に基づく振動実験解析法, 日本 機械学会論文集 C 編, Vol. 75, No. 760 (2009), pp. 3160-3167.

（3）細矢直基, 梶原逸朗, 細川恭彦, レーザーアブレーシ ヨンを用いたインパルス加振に基づく振動実験解析 法(FRF 計測における力計測のセンサレス化), 日本機 械学会論文集 C 編, Vol. 77, No. 773 (2011), pp. 102-113 